\title{
PROFIL KERUSAKAN NUKLEUS SEL HELA OLEH INDUKSI EKSTRAK ETHANOL CURCUMA LONGA
}

\author{
Denise Utami Putri ${ }^{1}$, Suryani Hutomo ${ }^{2}$, Heni Susilowati ${ }^{3}$ \\ ${ }^{1}$ Fakultas Kedokteran, Universitas Gadjah Mada \\ ${ }^{2}$ Bagian Mikrobiologi, Fakultas Kedokteran, Universitas Kristen Duta Wacana \\ 3BBagian Biologi Mulut, Fakultas Kedokteran Gigi, Universitas Gadjah Mada
}

Korespondensi: suryanihutomo_drg@yahoo.com

\begin{abstract}
ABSTRAK
Kunyit (Curcuma longa) merupakan tanaman yang dapat tumbuh di daerah tropis dan sub tropis dan banyak ditemukan di Indonesia. Kurkumin yang merupakan unsur utama kunyit, merupakan antioksidan yang kuat. Penelitian terdahulu melaporkan bahwa ekstrak etanolik Curcuma longa menyebabkan kematian separuh jumlah sel HeLa pada konsentrasi 184,5 $\mu \mathrm{g} / \mathrm{ml}$, dan sebagian besar merupakan apoptosis, tetapi profil kematian sel belum jelas. Penelitian ini dilakukan untuk mengetahui profil kematian sel akibat efek sitotoksisitas ekstrak kunyit pada cell line kanker serviks (HeLa) secara in vitro. Konsentrasi ekstak kunyit yang digunakan adalah $150 \mu \mathrm{g} / \mathrm{ml}$ dan $100 \mu \mathrm{g} / \mathrm{ml}$. Sel HeLa $\left(5 \times 10^{4} \mathrm{sel} /\right.$ well $)$ dikultur dalam RPMI 1640 semalam sebelum stimulasi. Ekstrak etanol kunyit (150 $\mu \mathrm{g} / \mathrm{ml}$ atau dan $100 \mu \mathrm{g} / \mathrm{ml}$ ) ditambahkan pada kultur HeLa dan diinkubasi selama 24 jam dalam medium tanpa antibiotik. Analisis profil kematian sel HeLa dilakukan dengan menggunakan mikroskop fluoresence setelah pewarnaan dengan Hoechst 33342. Doksorubisin $(0,5625 \mu \mathrm{g} / \mathrm{ml})$ digunakan sebagai kontrol positif induksi apoptosis. Hasil penelitian menunjukkan bahwa ekstrak Curcuma longa menyebabkan kerusakan sel yang ditandai dengan fragmentasi nukleus. Analisa statistik menunjukkan perbedaan yang bermakna antara kelompok kontrol negatif dengan kelompok stimulasi dalam jumlah sel yang mengalami kerusakan. Disimpulkan bahwa ekstrak Curcuma longa mampu menginduksi kerusakan sel HeLa yang mengarah pada apoptosis.
\end{abstract}

Kata kunci: ekstrak Curcuma longa, sel HeLa, kerusakan sel 


\title{
NUCLEAR DAMAGE PROFILE OF HELA CELLS INDUCED BY CURCUMA LONGA ETHANOLIC EXTRACT
}

\author{
Denise Utami Putri ${ }^{1}$, Suryani Hutomo ${ }^{2}$, Heni Susilowati ${ }^{3}$ \\ ${ }^{1}$ Fakultas Kedokteran, Universitas Gadjah Mada \\ ${ }^{2}$ Bagian Mikrobiologi, Fakultas Kedokteran, Universitas Kristen Duta Wacana \\ 3Bagian Biologi Mulut, Fakultas Kedokteran Gigi, Universitas Gadjah Mada
}

Korespondensi: suryanihutomo_drg@yahoo.com

\begin{abstract}
Curcuma mostly found in areas with tropical and sub-tropical climate. In Indonesia, curcuma can be found in almost all regions and areas. Curcumin, which is curcuma's main constituent, is a potent anti-oxidant. Previous study reported that $184.5 \mathrm{\mu g} / \mathrm{ml}$ Curcuma longa etanolic extract caused cell death in a half amount of HeLa cells mostly in apoptotic manner, but the cell death profile is unclear. The aim of this study is to investigate the cell death profile of HeLa cells stimulated with Curcuma longa etanolic extract. HeLa cells $\left(5 \times 10^{4}\right.$ cells/well) were cultured in complete RPMI 1640 overnight before stimulation. $150 \mu \mathrm{g} / \mathrm{ml}$ and $100 \mathrm{\mu g} / \mathrm{ml}$ Curcuma longa etanolic extract were added to the culture of HeLa cells and were incubated for 24 hours in antibiotic-free culture medium. HeLa cells cell death profile was analyzed under fluoresence microscope after staining using Hoechst 33342. Doxorubicin 10,5625 $\mathrm{mg} / \mathrm{ml}$ ) was used as positive control in this study. The results demonstrated that Curcuma longa extract caused nuclear fragmentation in most HeLa cells. Statistical analysis showed that there was significant difference between controls and treatment groups. It was concluded that Curcuma longa extract induced nuclear fragmentation in most HeLa cells, indicating apoptotic cell death mechanism.
\end{abstract}

Keywords: Curcuma longa extract, HeLa cells, cell fragmentation 


\section{INTRODUCTION}

Curcuma longa, or curcuma is commonly found in areas with tropical and sub-tropical climate. In India and South East Asia, rhizome of curcuma is widely used as spices and food ingredients. In addition, curcuma has also been used to traditionally aid wound healing. ${ }^{1}$ The yellow color of curcuma is derived from lipophilic polyphenol pigment known as curcuminoid. Curcuminoid is present in curcuma in a concentration of $2-9 \%$. Curcuminoid consists of some compounds such as curcumin, demethoxycurcumin and bisdemethoxycurcumin. Curcumin is one of the main constituent of curcuma, and has found to have a potent anti-oxidant effect. It is found to be comparable to vitamin $E$ and beta-carotene, which make curcuma a potential adjuvant therapy for liver protection and aging process. ${ }^{1}$

Besides acting as anti-oxidant, curcumin has also been found to have anti-viral, anti-fungal, and antiinflammation mechanism via the inhibition of some important inflammatory molecules. Antiinflammatory effect of curcuma is a combination of three important mechanism: histamine lowering mechanism, increases the production and prolong activity of cortisol synthetized by adrenal glands which has anti-inflammatory effect and improves blood circulation, to remove celular waste and inflamatory compound commonly trapped inside small joints. ${ }^{2}$

Previous studies have reported that curcumin can inhibit the growth of some cancer cell lines and induce apoptosis. The mechanism is postulated to be through inhibition of cell-signaling pathway of apoptosis. Transcription factors, oncogens, and signaling protein are found to be altered by curcumin. It has also been found to control cell cycle and stimulate cell apoptosis through regulation of $p 16$ and $p 53$ genes. ${ }^{3}$

It has also been reported that Curcuma longa ethanolic extract cause death of HeLa cells mostly by apoptotic manner, although some necrosis of cells were also found. ${ }^{4}$ The dose needed to cause death of half concentration of $\mathrm{HeLa}$ cells was found to be $184.5 \mu \mathrm{g} / \mathrm{ml}$ (unpublished data).

This study aims to observe nuclear damage profile of HeLa cells induced by Curcuma longa ethanolic extract.

\section{METHODS}

\section{Curcuma longa extraction}

Curcuma longa were obtained from Bantul District, Yogyakarta. Extraction was done by maceration technique. Nine months old rhizomes of Curcuma longa were made into powder (simplicia) and placed into a container. Ethanol was added for dilution in 10:1 ratio. Simplicia were left soaked in ethanol for 24 hours with periodic stirring. Filtrates were placed into different container. Dregs from previous filtration were further soaked with 96\% alcohol for three times. Filtrates were then evaporated using evaporator machine, and resulted a semi-solid ethanolic extract of Curcuma longa. Extracts were then dried inside $40^{\circ} \mathrm{C}$ oven.

\section{HeLa cells culture}

HeLa cells were cultured in RPMI 1640 media (Sigma-Aldrich, St Louis, MO, USA) and supplemented with 10\% $\mathrm{FBS}, 100 \mathrm{IU} / \mathrm{ml}$ penicilin, and $10 \mu \mathrm{g} / \mathrm{ml}$ streptomycin, incubated on $37^{\circ} \mathrm{C}$ with $5 \%$ of $\mathrm{CO}_{2}$. Cells were incubated to obtain a confluent amount of cells needed. HeLa cells were harvested by adding $1-2 \mathrm{ml}$ of $0.25 \%$ tripsin into the flask and left for few minutes before then moved into conical tubes. RPMI was added to make $10 \mathrm{ml}$ volume. Cells 
are centrifuged at 2000 rpm for 5 minutes.

Supernatants were thrown away. Pellets were resuspended in $1 \mathrm{ml}$ of media and counted using chamber. Cell suspension was moved into 24 wellplate covered with coverslip. Media were added to yield cell concentration of $5 \times 10^{4}$ cells/ $100 \mu l$ and ready to be used.

\section{Observation of nuclear damage of HeLa Cells}

Curcuma longa ethanolic extract was diluted into $1 \mathrm{mg} / \mathrm{ml}$ dimethylsulfoxide (DMSO) solution, aliquoted and stored in $-20^{\circ} \mathrm{C}$ freezer. Extract solution in DMSO was further diluted into RPMI media without antibiotic to yield concentration of 100 and $150 \mu \mathrm{g} / \mathrm{ml}$.

After 24 hours of incubation, cells were grouped into control and treatment groups each in quadruplet. HeLa cells on control group were cultured with culture media and acted as negative control, while cells on treatment group were exposed to 100 and $150 \mu \mathrm{g} / \mathrm{ml}$ Curcuma longa ethanolic extract. For positive control, cells were treated with $0.5625 \mu \mathrm{g} / \mathrm{ml}$ doxorubicin.

Cells were incubated for 24 hours. RPMI media were washed and replaced with phosphate buffer saline (PBS 1x) and fixated using 10\% formalin. Lastly, cells were washed using PBS $1 x$ and stained using Hoechst 33342 (Sigma, St Louis, Missouri, USA) for five minutes. Observation was done under fluorescence microscope after mounting the coverslips on glass slides. Cells were observed and count in 10 fields of view. Experiments were done three times to yield consistent result.

\section{STATISTICAL ANALYSIS}

Calculation of HeLa cells underwent damage by nuclear fragmentation were quantified in percentage (\%), and were representative data from three times experiment. Data were shown to be distributed normally using Shapiro-Wilk and Levene Test $(p$ $>0.05$ ), but were inhomogenous ( $p<$ 0.05). Percentage of cell damage analysis were done using Kruskal Wallis analysis, and were shown to be statistically significant $(p<0.05)$.

\section{RESULTS}

Normal HeLa cells' nuclei are stained blue with Hoechst 33342, compact, and round in shape (Figure 1A). HeLa cells cultured without exposure act as negative control. The study shows that HeLa cells underwent cell death by nuclear fragmentation after exposed with 100 and $150 \mu \mathrm{g} / \mathrm{ml}$ Curcuma longa ethanolic extract, indicated by nuclear shrinkage and formation of condensed chromatin absorbing bisbenzimide H33342 particles from Hoechst staining. It was seen under fluorescence microscope as scattered blue dots in fig $1 B$ and $1 C$, respectively. HeLa cells exposed to doxorubicin act as positive control, are observed to have the most nuclear damage (Figure 1D). 


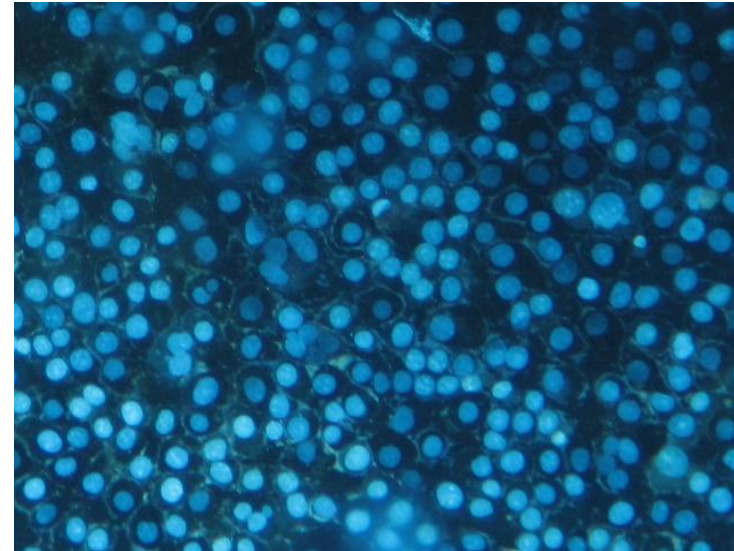

A

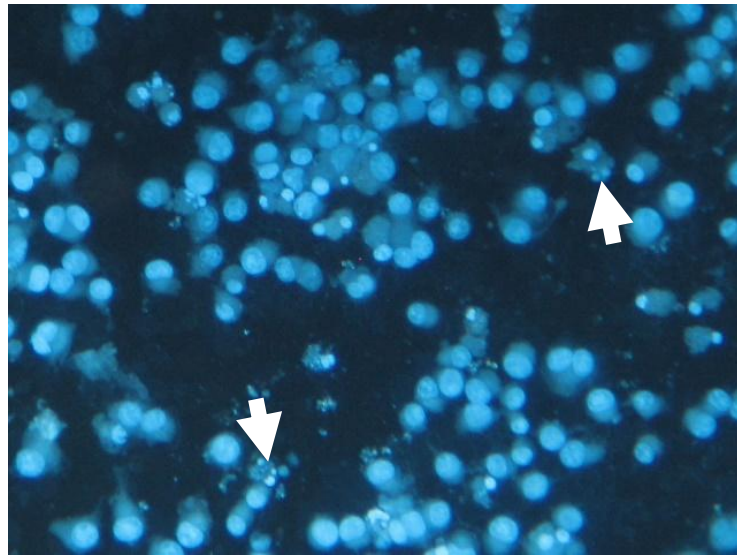

C

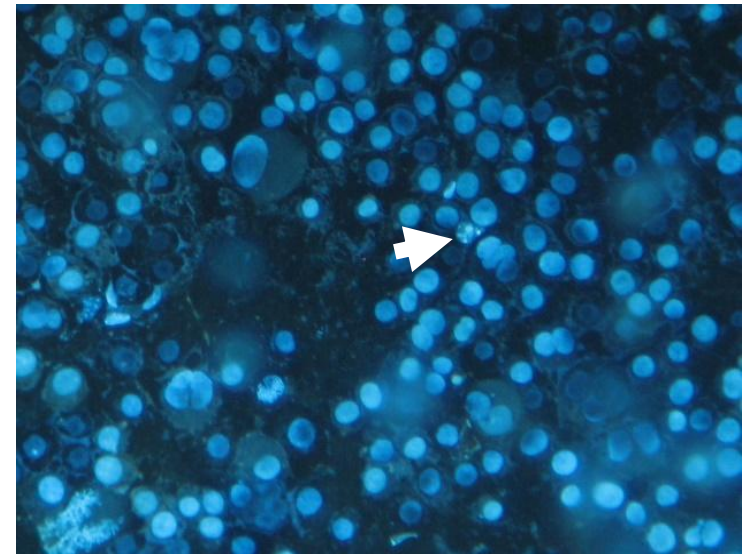

B

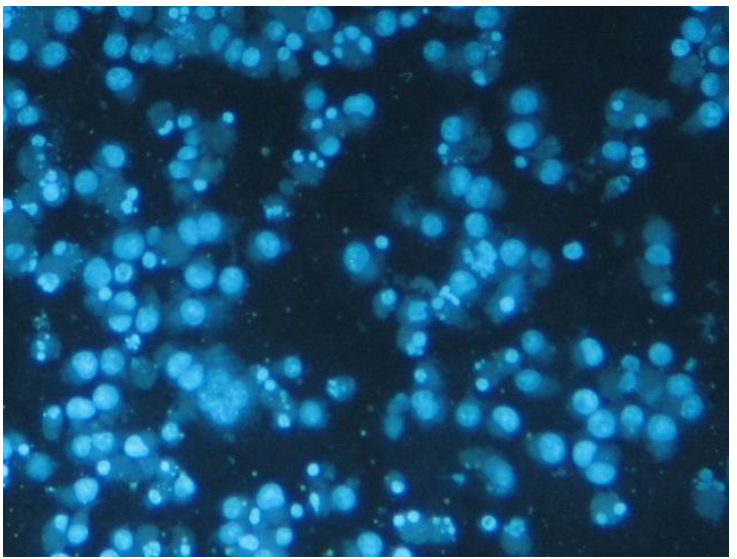

$\mathrm{D}$

Figure.1. HeLa cells incubated without exposure, with blue compact round shaped nuclei (A). HeLa cells exposed to Curcuma longa ethanolic extract $100 \mu \mathrm{g} / \mathrm{ml}(\mathrm{B})$, and $150 \mu \mathrm{g} / \mathrm{ml}(\mathrm{C})$, Underwent cellular damage by nuclear fragmentation as seen with scattered bright blue dots surrounded by its paler blue cytoplasm (arrows). HeLa cells exposed to doxorubicin act as positive control with the most cell damage by nuclear fragmentation (D), Hoechst 33342 stained.

Data show that exposure of 100 and $\mu \mathrm{g} / \mathrm{ml}$ Curcuma longa ethanolic extract caused mean cell damage of $10.42 \%$ and $28.01 \%$, respectively, as may be seen in Table 1.

Table 1. Mean and Standard Deviation (SD) of nuclear cell damage of HeLa cells (in \%)

\begin{tabular}{cccc}
$\begin{array}{c}\text { Negative } \\
\text { control }\end{array}$ & $\begin{array}{c}100 \mu \mathrm{mg} / \mathbf{m l} \\
\text { Curcuma longa } \\
\text { ethanolic } \\
\text { extract }\end{array}$ & $\begin{array}{c}\mathbf{1 5 0} \boldsymbol{\mu g} / \mathbf{m l} \\
\text { Curcuma longa } \\
\text { ethanolic } \\
\text { extract }\end{array}$ & $\begin{array}{c}\text { Positive } \\
\text { control }\end{array}$ \\
\hline $0.95 \pm$ & $10.42 \pm 0.18$ & $28.01 \pm 0.06$ & $79.78 \pm$ \\
0.05 & & & 0.31 \\
\hline
\end{tabular}

Shapiro-Wilk test was used to analyze normality of the data. $P$ value of control and exposure groups were found to be above 0.05, which indicated that data were distributed normally.
Then Levene test was done to test data homogeneity, but based on mean, pvalue was 0.036 which indicated that data were not homogeny. 
To analyze whether Curcuma longa ethanolic extract induced nuclear cell damage on HeLa cells, KruskalWallis analysis were done, and was shown to have $p$ value of 0.00 , so it may later be concluded that statistical test showed significant results.

\section{DISCUSSION}

Study shows that ethanolic extract of Curcuma longa induce cell damage on HeLa cells, mostly seen by nuclear fragmentation. This mode is suggestive of apoptotic cell death mechanism and confirms previous study by Hutomo, which concluded that Curcuma longa ethanolic extract induce HeLa cells damage more by apoptosis than necrosis $(28,87 \%$ apoptosis and $12.15 \%$ necrosis). ${ }^{4}$

Apoptosis is a highly coordinated mechanism of cell death mediated mostly by active intrinsic factors, although extrinsic factors can also contribute. Apoptosis may happened during physiologic and pathologic condition, to maintain tissue homeostasis, where immune cells, T cells and $B$ cells died during maturation process, and to remove damaged and infected cell.5,6 It is genetically controlled and is defined by cytoplasmic and nuclear shrinkage, chromatin margination, and breakdown of the cell into multiple spherical bodies that retain membrane integrity.

In apoptosis, the earliest change occurs in the nucleus with chromatin condensation, pyknosis and kayrorrhexis. Condensed chromatin may appears as crescents along the periphery of the nuclear membrane, or as spherical bodies within nucleus. It further leads to cell shrinkage and vacuoles are formed within the cytoplasm. Apoptotic bodies are formed by condensed cytoplasm along with fragmented chromatin, and may contain functional mitochondria and other organelles. In vivo, these apoptotic bodies are phagocytosed by neighboring cells, while in vitro, they undergo swelling and eventual lysis, also known as secondary necrosis. ${ }^{7}$

Factors contributing to necrosis are mostly extrinsic in nature, such as osmotic gradient difference, thermal exposure, hypoxic-ischemic process, toxic induced, and traumatic insults. Cells undergoing necrosis rapidly loss its membrane integrity, followed by influx of $\mathrm{Na}^{+} . \mathrm{Ca}^{2+}$, and water into the cell resulting in cytoplasmic swelling and nuclear pyknosis. Lysosomal and granular contents are then released into surrounding extracellular space resulting in inflammation.

Necrotic cells have a very distinct morphology compared to apoptotic cells, with main characteristic of chromatin flocculation, swelling and degeneration of entire cytoplasm and mitochondrial matrix, blebbing of plasma membrane, and release of cytoplasmic contents into extracellular space. While in apoptotic cells chromatin is packed into membrane-bound particles, necrotic cells are formed in irregularly shaped clumps. The mitochondria undergo inner membrane swelling, cristeolysis, and disintegration. Dense and granular appearance are commonly seen and are caused by dissociated polyribosome throughout the. ${ }^{8}$

Nuclear shrinkage and condensed chromatin are able to absorb bisbenzimide H33342 particles contained in Hoechst staining. And with observation under fluorescence microscope, nuclear fragmentation is seen as scattered blue dots indicating cell damage, suggestive of apoptosis mechanism of cell damage. Further studies are needed to observe cellular and molecular mechanism of apoptosis on HeLa cell which acts as epithelial cell cancer model, on inducement by specific constituent of Curcuma longa. ${ }^{9}$ 


\section{CONCLUSION}

Curcuma longa ethanolic extract caused nuclear cell damage on HeLa cells, suggestive of apoptosis mechanism of cell death.

\section{ACKNOWLEDGEMENT}

Acknowledgement is given unto Laboratorium Pengujian dan Penelitian Terpadu (LPPT) Universitas Gadjah Mada Yogyakarta.

\section{REFERENCE}

1. Nayak, P.L. Curcumin: a wonder anticancer drug. International Journal PhramBiomed, 60-69.

2. Akram, M. Curcuma longa and curcumin. Journal Biol. - Plant Biol., 2010 (55):65- 70.

3. Wilken Reason. Curcumin: A review of anti-cancer properties and therapeutic activity in head and neck squamous cell carcinoma. Molecular cancer. 2011. (accessed from: http:/ /www.molecular-cancer.com/ content/10/1/12).

4. Hutomo, S., Kurniawan, C., Tipe Kematian Sel HeLa setelah
Paparan Ekstrak Etanolik Curcuma longa. Berkala Ilmiah Kedokteran Duta Wacana. 2015. vol 01:01

5. Elmore S. Apoptosis: A review of programmed cell death. ToxicolPathol. 2007. 35(4): 495516.

6. Porth CM and Matfin G. Pathophysiology. Concepts of Altered Health States. $8^{\text {th }}$ ed. Lippincott Williams \& Wilkins. Philadelphia. USA. 2012: 94-111

7. Zhang, HJ, Xu, M. 2000. DNA fragmentation in apoptosis. Cell Research 2000; 10, 205-211

8. Zhivotosky B Assessment of apoptosis and necrosis by DNA fragmentation and morphological criteria. CurrProtoc Cell Biol. 2001 Nov; Chapter 18:Unit 18.3

9. Wu J, Apontes P, Song L, Liang P, Yang L, Li F. Molecular mechanism of upregulation of surviving transcription by the AT-rich DNAbinding ligand, Hoechst33342: evidence for surviving involvement in drug resistance. Nucleic Acids Res 2007; 35(7): 2390-2402 